\title{
Effects of one resistance training session on body checking behaviors in male adults
}

http://dx.doi.org/10.11606/1807-5509201800010025

\author{
Leonardo de Sousa FORTES* \\ Maria Elisa Caputo FERREIRA** \\ Jeferson Macedo VIANNA** \\ Liliane Cunha ARANDA** \\ Edilson Serpeloni CYRINO****
}

*Universidade Federal

da Paraíba, João

Pessoa, PB, Brasil.

${ }^{* *}$ Universidade

Federal de Juiz de

Fora, Juiz de Fora,

MG, Brasil.

${ }^{* * *}$ Universidade

Estadual de Londrina,

Londrina, PR, Brasil.

\begin{abstract}
The objective of this study is to analyse the effects of a session of resistance training on body checking in male adults. Participants included 50 volunteers aged between 18 and 30 years. A single session of resistance training was performed, and we used hypertrophy as our training method. Body checking behaviors were assessed using the Male Body Checking Questionnaire (MBCQ). Participants answered the MBCQ before (T1), immediately after (T2), and $24 \mathrm{~h}$ (T3), $48 \mathrm{~h}$ (T4) and $72 \mathrm{~h}$ (T5) after the resistance training session. The findings showed no difference in the subscale "compared to other people" ( $p=0.32)$. However, statistically significant differences were found for the subscales "use of reflective surface" ( $p=0.03)$, "check by clamping" $(p=0.04)$ and "evaluation by others" ( $p=0.02)$. We concluded that a single session of resistance training was able to positively change some body checking behaviors of male adults.
\end{abstract}

KEYwORDS: Body image; Exercise; Resistance Training.

\section{Introduction}

Body image is a multifaceted construct, and body checking is one of its components ${ }^{1}$. According to Walker, Anderson and Hilderbrandt ${ }^{2}$, the following are considered behaviors of male body checking: comparing one's body with another man's body, groping or pinching the muscles, examining the size of one's muscles in a mirror and asking others to confer the development of one's muscles. Accordingly, it appears that body checking behaviors may predispose individuals to the onset of male muscle dysmorphia ${ }^{3}$, which is considered a psychological issue associated with changes in body perception $^{4}$. It appears that approximately $50 \%$ of men show body checking behaviors routinely ${ }^{2}$. Data indicate that approximately $20 \%$ of men with high frequency of body checking are diagnosed with body dysmorphic disorder ${ }^{3}$.

Moreover, it is noteworthy that the body checking behaviors are related to the onset of eating disorders ${ }^{1}$. Therefore, intervention methods that have the premise to mitigate the frequency of body checking may be effective in preventing to eating disorders. While there is evidence indicating that exercise can positively influence the components of body image $e^{5-8}$, other findings do not support this line of reasoning ${ }^{1,9}$. However, it is stressed that the investigations in this area did not employ experimental or quasiexperimental designs wherein physical training such as intensity and type of exercise were controlled. There are many types of exercise, such as aerobic activities in a cyclic orientation (running, swimming, cycling, and rowing), anaerobic exercises in an acyclic orientation (team sports) and exercises focused on aesthetics (resistance training). Currently, resistance training is one of the most popular forms of exercise for fitness improvement ${ }^{10-11}$. Among the different forms of resistance training, there is the practice of similar strength exercises, which are characterized by concentric and eccentric muscle action alternation using a fixed resistance ${ }^{12-13}$. The evidence shows that resistance training can increase strength, power, muscle volume ${ }^{14}$, and bone mass as well as thicken 
connective tissue and decrease total body fat 11 , all of which are valued in Western cultures ${ }^{15}$. Accordingly, it is assumed that resistance training is effective in mitigating the behaviors of the body checking ${ }^{16}$.

However, given that these benefits are achieved, some points for consideration include the individualization of the training program, progression and control of overload. In addition, there are acute variables of strength training, such as exercise selection, order of exercises, number of sets, intensity (load used), duration of rest, and speed and frequency of training ${ }^{14}$.

Among these variables, the load used is considered by some researchers as the variable that is most important to control for when designing a

\section{Methods}

This is a quasi-experimental research conducted with young male adults who have previous experience in resistance training.

\section{Participants}

The sample, selected in a non-probabilistic way, consisted of 50 male volunteers aged between 18 and 30 years. All participants had engaged in resistance training for a minimum of 6 consecutive months. The volunteers indicated no history of musculoskeletal injury and had not used ergogenic aids (whey-protein or creatine) for optimum strength or muscle volume.

\section{Instruments}

\section{4-10 repetition maximum $(\mathrm{RM})$ test}

Muscle strength was determined by using the 4-10 RMs test. We used the equations from EpLeY $^{20}[1 \mathrm{RM}=(0.0333 \mathrm{x}$ reps $) \times$ submaximal load + submaximal load) $]$ and ADAMs ${ }^{21}[1 \mathrm{RM}=$ submaximal load / [100 - (2 x reps $)] \times 100]$ to predict the values of the participants' $1 \mathrm{RM}$ of exercise for upper and lower limbs, respectively, based on the findings of Meneses et al. ${ }^{22}$. The exercises included bench press, leg extension, strength training program ${ }^{17}$, as this is this variable that will delimit the correct number of repetitions and the time needed for recovery between sets and exercises ${ }^{18}$. Consequently, the load used determines the effects of training on strength development and on the associated morphological adaptations ${ }^{11}$. However, no prior research that has examined the effects of exercise on components of body image controlled for intensity ${ }^{5-8}$. In addition to intensity, researchers also note that the order of the exercises may be important for increasing lean mass and reducing body fat ${ }^{14,19}$. Nonetheless, to date, the acute effects that resistance training may have on various components of body image are still unclear ${ }^{6}$.
After receiving information on the study methods, the participants signed an informed consent form (ICF). The procedures adopted in this study met the requirements of Resolution 466/12 of the National Board of Health for research on humans, and approval was granted by the Research Ethics Committee.

driven pulley, leg flexion, lateral shoulder raise and a triceps pulley (Righetto ${ }^{\circ}$ brand). For each exercise, the participant was allowed two attempts to successfully complete 4-10 RMs, with an interval of three to five minutes between attempts and exercises ${ }^{23}$. The majority of the $1 \mathrm{RMs}$ were performed on different days at an interval of 48 hours. The maximum number of repetitions at $80 \%$ of $1 \mathrm{RM}$ was tested. Therefore, individuals performed each exercise until concentric failure based on the pace of implementation, which was 
determined by an electronic metronome (Qwik Time ${ }^{\oplus}$ TM, China). A rate of $40 \mathrm{bpm}$ with a beat and a half for each phase was used, which corresponds to 1.5 seconds for the concentric phase and 1.5 seconds for the eccentric phase of the movement ${ }^{24}$ with no pauses allowed between phases of contraction.

Before beginning the evaluation, we used a familiarisation protocol with the 4-10 RM to reduce the effects of learning new motor gestures ${ }^{25}$. All participants were tested similarly to the protocol in three separate sessions with intervals of 48 hours.

\section{Resistance training session}

A single resistance training session was conducted. The session consisted of the exercises performed in the following order (multiarticulars to monoarticulars): bench press, leg extension, driven pulley, leg flexion, lateral shoulder raises and triceps pulley. Participants performed a series of 10 repetitions, and intensity was determined subjectively according to fatigue and heating for the first two exercises. In all cases, the recovery interval between sets and exercises was 120 seconds $^{26}$.

Moreover, using hypertrophy training, we adopted two series with 10 RMs for all exercises and 120 seconds of rest between each set and each exercise. A metronome was used to control the speed of implementation, adopting a rate of $40 \mathrm{bpm}$ (1.5 seconds for each contraction phase).

\section{Body checking behaviors}

Body checking behaviors were assessed using the Male Body Checking Questionnaire (MBCQ). The MBCQ consists of four subscales: 1) comparison to other people, i.e., the frequency that the participant compares the size of the muscles or the amount of body fat with others; 2) use of reflective surface, i.e., the frequency that the participant looks in the mirror to observe any part of the body; 3) check by clamping, i.e., the frequency with which the participant "tweaks" or stretches the skin to check or highlight parts of the body; and 4) review of body by others, i.e., the seeking of comments from others about muscles (size and resolution). The MBCQ was validated in the Brazilian population of young males, demonstrated good psychometric properties ${ }^{27}$, and showed good internal consistency (Cronbach's alpha $=.92$ to .95 ) in all stages of research.

\section{Body dissatisfaction}

We used the Drive for Muscularity Scale (DMS) to evaluate the participants' motivation for muscularity ${ }^{27}$. The scale consists of a self-administered questionnaire consisting of 12 items scored using a Likert-type scale $(1=$ never to $6=$ always $)$. The DMS aims to assess the level of concern and desire to be more muscular. The higher the score is, the higher the drive for muscularity. The validation study of the DMS demonstrated good psychometric properties for Brazilian men ${ }^{28}$. The present study returned a Cronbach's alpha of .91, representing good internal consistency of the DMS. Because some findings suggest the drive for muscularity influences body checking behaviors ${ }^{2}$, we monitored the scores of the DMS in the statistical analyses.

\section{Anthropometry}

To determine body mass and height, a portable scale $\left(\right.$ Tanita $\left.{ }^{\oplus}\right)$ and a stadiometer $\left(\right.$ Welmy ${ }^{\oplus}$ ) were used. Measurements were made in accordance with the procedures of the International Society for the Advancement of Kinanthropometry ${ }^{28}$. The body mass index (BMI) was calculated using the following formula: $\mathrm{BMI}=$ body mass $(\mathrm{kg}) /$ height $(\mathrm{m})^{2}$.

Body composition was determined using the skinfold thickness technique, along with the compass Lange $^{\odot}$ (USA), on the chest, triceps and subscapular skinfolds according to the protocol of JACKSON and Pollock ${ }^{29}$. For all these measurements, we used the pattern of the International Society for the Advancement of Kinanthropometry ${ }^{30}$.

Because scientific investigations indicate the influence of body fat percentage and BMI in constructs of body image ${ }^{31}$, we controlled for these variables in the statistical analyses.

\section{Procedures}

The participants were first invited to participate in the study. The ICF was then distributed, and they were asked to return the signed form the following week, thereby indicating their voluntary participation in the study.

After receiving consent of the participants, the research was conducted in 7 steps. It was recommended that participants follow their daily diets. However, engaging in extra physical activities during the research process was not allowed. 
Phase 1 consisted of three sessions of familiarisation at an interval of 48 hours between them, with a total duration of one week. Step 2 followed the initial week of familiarisation and consisted of the 4-10 RM tests and anthropometric assessments. In the 4-10 RM tests, participants were asked to perform as many repetitions as possible. Verbal encouragements were offered during the measurements. For anthropometry, participants wore minimal clothing. Step 3 followed 48 hours after Step 2. Step 3 required the participants to complete the DMS questionnaire and the MBCQ 30 minutes before the resistance training session (S1). This constituted the pre-test (T1). Step 4 involved applying the MBCQ 30 minutes after S1. This constituted the post-test (T2). In steps 5 (T3), 6 (T4) and 7 (T5), the participants answered the MBCQ, respectively, 24, 48 and 72 hours after T2.

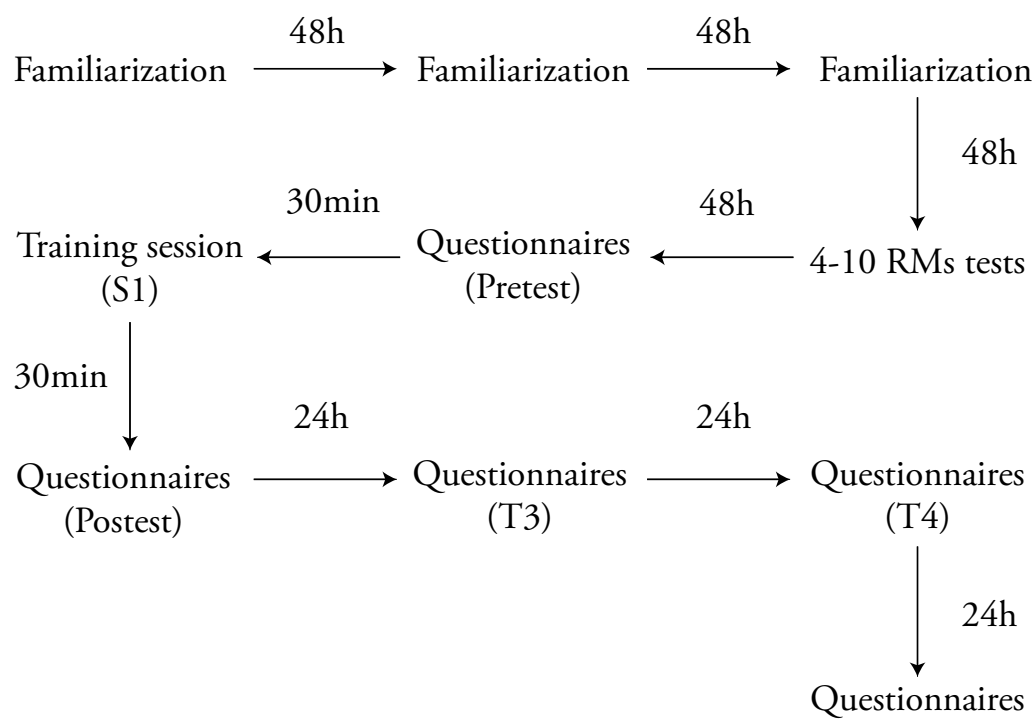

(T5)

FIGURE 1 - Experimental design of study.

\section{Data Analysis}

We used the Shapiro Wilk test to assess the distribution of data. Levene's test was used to test the homoscedasticity, while the sphericity of the data was verified using the Mauchly test. When this last assumption was violated, the Greenhouse-Geisser correction was adopted. We used measures of central tendency (mean) and dispersion (standard deviation) to describe the variables of the research. A repeated measures
ANOVA was used to compare the scores on the MBCQ subscales according to time search (T1, T2, T3, T4 and T5). The post hoc Bonferroni test was applied to identify possible significant differences. Furthermore, we calculated the effect size, represented by the symbol " $\mathrm{d}$ ", to indicate differences from a practical standpoint. Notably, scores on the DMS, body fat percentage and BMI were controlled for in the statistical tests. All data were processed using SPSS 20.0 software, adopting a significance level of $5 \%$.

\section{Results}

Descriptive data on age, BMI, body fat percentage and values of $1 \mathrm{RM}$ (bench press, leg extension, driven pulley, leg flexion, lateral shoulder raise and triceps pulley) are presented in TABLE 1.
Concerning the comparison of the MBCQ subscales according to research stages (T1, T2, T3, T4 and T5), the ANOVA repeated measures results are highlighted in TABLE 2 . Accordingly, the 
results indicate that a) no difference was found in the subscale "comparison to other people" $\left(F_{(4,46)}=\right.$ $1.44 ; p=0.32 ; d=0.1)$ and b) statistically significant differences were found for the subscales "use of reflective surface" $\left(F_{(4,46)}=11.55 ; p=0.03 ; d=0.4\right)$, "check by clamping" $\left(F_{(4,46)}=8.71 ; p=0.4 ; d=0.4\right)$ and "review of body by others" $\left(F_{(4,46)}=17.90\right.$; $p=0.02 ; d=0.5)$. It was also found that the DMS $\left(F_{(1,49)}=84.22 ; p=0.001\right)$ and body fat percentage $\left(F_{(1,49)}=14.33 ; p=0.04\right)$ showed collinearity with the MBCQ scores, while BMI showed no collinearity $\left(F_{(1,49)}=1.49 ; p=0.29\right)$.

TABLE 1 - Descriptive data (mean and standard deviation) of research variables.

\begin{tabular}{lcc}
\hline Variables & Mean & Standard Deviation \\
\hline Age (years) & 24.20 & 2.33 \\
BMI $\left(\mathrm{kg} / \mathrm{m}^{2}\right)$ & 26.55 & 2.89 \\
Body fat percentage & 17.67 & 7.11 \\
1RM Bench press $(\mathrm{kg})$ & 73.71 & 18.92 \\
1RM Leg extension $(\mathrm{kg})$ & 199.21 & 70.37 \\
1RM Driven pulley $(\mathrm{kg})$ & 86.95 & 14.87 \\
1RM Leg flexion $(\mathrm{kg})$ & 90.2 & 17.57 \\
1RM Lateral shoulder raises $(\mathrm{kg})$ & 15.71 & 4.13 \\
1RM Triceps pulley $(\mathrm{kg})$ & 38.34 & 9.32 \\
Drive for Muscularity Scale & 32.53 & 14.53 \\
\hline
\end{tabular}

$\mathrm{BMI}=$ Body mass index; $\mathrm{RM}=$ Repetition maximum.

TABLE 2 - Mean and standard error of MBCQ subscales according to research step.

\begin{tabular}{lccccc}
\hline Subscale/Step & T1 & T2 & T3 & T4 & T5 \\
\hline COP & $14.00(1.12)$ & $13.00(1.82)$ & $14.46(1.84)$ & $13.23(1.87)$ & $12.15(2.07)$ \\
URS & $16.53(1.22)$ & $13.92(1.97)^{\mathrm{a}}$ & $16.15(1.64)$ & $15.38(1.69)$ & $13.84(2.11)$ \\
CP & $4.00(0.33)$ & $3.61(0.50)$ & $3.84(0.49)$ & $4.07(0.53)^{\mathrm{b}}$ & $3.38(0.56)^{\mathrm{d}}$ \\
RBO & $2.15(0.15)$ & $1.84(0.24)^{\mathrm{a}}$ & $2.15(0.22)^{\mathrm{b}}$ & $2.15(0.23)^{\mathrm{b}}$ & $2.00(0.28)$ \\
MBCQ & $36.69(1.63)$ & $32.38(4.16)^{\mathrm{a}}$ & $36.61(3.73)^{\mathrm{b}}$ & $34.84(3.84)$ & $31.38(4.70)^{\mathrm{a}}$ \\
\hline
\end{tabular}

\section{Discussion}

The study aimed to analyse the effects of a resistance training session on body checking behaviors of male adults. On one hand, evidence pointed to the influence of exercise on the components of body image ${ }^{5-8}$; on the other hand, findings did not demonstrate a relationship between physical activity and body image ${ }^{1,9}$. It is noted, however, that in previous investigations, no study controlled for the acute variables of physical training such as frequency, duration, intensity, density and speed of execution ${ }^{19}$, which are all variables that can determine the psychological training responses ${ }^{17}$. In this sense, studies that control for frequency, duration, intensity, density and speed of execution in resistance training protocols are needed to clarify the effects of exercise on the subconstructs of body image.

The findings of this research did not suggest a change in the behaviors of body comparisons with others. The results indicate that the frequency with which the participants compared their body morphology with other men did not change as a result of the resistance training session. Accordingly, a single resistance training session using approximately $80 \%$ of the $1 \mathrm{RM}$ in the exercises for upper and lower body induces positive effects on body comparison behaviors in men. It has been noted previously that body checking behaviors based on social comparisons were not modified by physical exercise, but by sociocultural influences (e.g., friends, family and media) ${ }^{7}$, which explains the
$\mathrm{COP}=$ comparison to other people; URS = use of reflective surface; $\mathrm{CP}=$ check by "clamping"; $\mathrm{RBO}=$ review of body by others; $\mathrm{MBCQ}=$ Male Body Checking Questionnaire; T1 = Pre-test; $\mathrm{T} 2=$ Pos-test; $\mathrm{T} 3=24 \mathrm{~h} ; \mathrm{T} 4=48 \mathrm{~h}$; $T 5=72 \mathrm{~h} ; \mathrm{a}<<0.05$ relation to a $\mathrm{T} 1$; ${ }^{b} p<0.05$ relation to a $\mathrm{T} 2$; $\mathrm{d} p<0.05$ relation to $\mathrm{a}$ T4. 
results for the subscale "compared to other people". It is considered important to seek interventions that can reduce the frequency of body comparisons between men, because this kind of behavior is associated with the onset of eating disorders ${ }^{1}$.

Regarding the "use of reflective surface" subscale, the results indicated a decrease in the frequency of body checking in the mirror immediately after the training session compared to the previous session. In other words, a resistance training session may reduce the frequency with which men observe the size and shape of their muscles in the mirror. However, due to the increase of the mean "use of reflective surface" subscale in T3 and T4 stages, it seems that the frequency of body checking in the mirror reverts to baseline levels, despite not showing a significant difference compared to T2. Thus, it is possible that the frequency of body checking behaviors in mirrors will decrease if the resistance training becomes an everyday practice among participants, as revealed in the study of ForTes et al. ${ }^{16}$. It should be emphasised, however, that the perception of low muscle volume coming from muscle checking behavior in the mirror can result in maintaining or increasing the magnitude of the drive for muscularity ${ }^{2}$. Thus, a vicious cycle may occur if body checking becomes a common behavior among men who desire to become more muscular. Accordingly, more research must be conducted to clarify whether resistance training attenuates the magnitude of muscle checking behavior in mirrors.

Regarding the "check by clamping" subscale, the findings showed no effects after the resistance training session. However, the frequency of muscle pinching increased 48 hours (T4) after the resistance training session. According to this result, it seems that two physically inactive days for participants who are accustomed to resistance training may be sufficient to generate negative effects on the frequency of muscle clamping, whereas a resistance training session can result in momentary morphological changes (increased muscle size and reduced body weight ${ }^{11}$. Furthermore, two days without resistance training can make the individual feel fatter ${ }^{9}$, which may explain the increased frequency of pinching in T4 compared to T2. On the other hand, a reduction in the frequency of pinching in T5 compared to T4 was not expected. Perhaps, the frequency of pinching in T4 was influenced by sociocultural factors (friends, family and media), which are characteristics that were not controlled for in this study. In this regard, comments from friends and family concerning body image may have impacted body checking behaviors in $\mathrm{T} 4$ and $\mathrm{T} 5$. Therefore, we cannot say with certainty that these differences were derived from the resistance training session. Future studies should control for sociocultural influences when evaluating the effects of physical training on body image constructs.

For the subscale "review of body by others", one session at $80 \%$ of $1 \mathrm{RM}$ was effective in reducing the frequency of requests for other people to comment on the participant's muscles. However, 24 hours without exercise was sufficient to cause an increase in the frequency of requests for other people to comment on the size and shape of the muscles and to increase comments regarding muscle definition. Although the frequency of reviews by others at $\mathrm{T} 4$ remained stable at $\mathrm{T} 5$, the magnitude of the frequency of these behaviors decreased, which was not expected. Based on the sociocultural model of body image ${ }^{15}$, the positive comments coming from friends, as well as the reduced access to sport and fashion magazines, may have led to the reduction in the frequency of requests for other people to comment on their muscles. Notably, however, sociocultural factors were not controlled for in this study.

This research fills a small gap in the existing research regarding body checking behaviors of adult males. However, there are some limitations associated with this study. One limitation was the use of the MBCQ as the main instrument, as researchers have noted that self-report measurement tools are unreliable ${ }^{7,27}$. Accordingly, the results may not reflect the reality of the context evaluated, as the end result was based on subjective self-report responses. Researchers emphasise the relevance of these instruments provided that their psychometric qualities have been established ${ }^{31}$. Another limitation was not to analyze the presence of body image issues prior to the survey, for example, body dysmorphic disorder. Thus, the results should be treated with caution. It should be noted that the analysis of body checking until 72 hours after resistance training session does not infer the findings of this research in the medium/long term to the subjects that continue training. Also noteworthy is the use of the doubly indirect method for estimating body fat due to the difficulty in accessing sophisticated equipment and the high financial expense in the use of these devices. Despite these limitations, it is believed that the present study reveals important findings worthy of discussion in the scientific literature.

The results showed that a single session of resistance training positively changed some body checking behaviors (reduced the frequency of 
the use of mirrors and requests for other people's comments about the muscles) of male adults. It is noteworthy, however, that this finding may be related to the training method used (hypertrophy) or to the order of the execution of exercises (multiarticular movements and monoarticular movements). Therefore, further research is needed to assess the effects of other methods of resistance training and the effects of the order of exercises on body checking behaviors.

We encourage further studies with females to examine the effects of resistance training on constructs of body image. In addition, we recommend that studies include a range of 4 to 24 weeks of resistance training to evaluate the effects of short-, medium- and longterm training on body checking behaviors in adults.

\section{Resumo}

Efeitos de uma sessão de treinamento resistido sobre os comportamentos de checagem corporal em adultos do sexo masculino

0 objetivo foi analisar os efeitos de uma sessão de treinamento com pesos sobre a checagem corporal de adultos do sexo masculino. Participaram 50 voluntários com idade entre 18 e 30 anos. Foi realizada uma única sessão de treinamento com pesos e utilizou-se o método de treino denominado "Hipertrofia". Os comportamentos de checagem corporal foram avaliados pelo Male Body Checking Questionnaire (MBCO). Os sujeitos responderam o MBCQ antes (T1), logo após (T2), 24h (T3), 48h (T4) e 72h (T5) após o término da sessão de treinamento com pesos. Os achados não demonstraram diferença na subescala "comparação com outras pessoas" ( $p=0,32)$. Todavia, foram evidenciadas diferenças estatisticamente significativas para as subescalas "uso de superficie reflexiva $(p=0,03)$, "checagem por meio de pinçamento" $(p=0,04)$ e "avaliação por outras pessoas" $(p=0,02)$. Concluiu-se que uma única sessão de treinamento com pesos foi capaz de alterar positivamente alguns comportamentos de checagem corporal de adultos do sexo masculino.

PalaVRAS-Chave: Imagem corporal; Exercício físico; Treinamento com pesos.

\section{References}

1. Smith AR, Hawkeswood SE, Bodell LP, Joiner TE. Muscularity versus leanness: An examination of body ideals and predictors of disordered eating in heterosexual and gay college students. Body Image. 2011;8(2):232-236.

2. Walker DC, Anderson DA, Hilderbrandt T. Body checking behaviors in men. Body Image. 2009;6:164-170.

3. Didie ER, Kuniega-PietrzakT, Phillips KA. Body image patients with body dysmorphic disorder: evaluations of and investiment in appearance, health-illness, and fitness. Body Image. 2010;7(1):66-69.

4. Azevedo AP, Ferreira AC, Da Silva PP, Caminha IO, Freitas CM. Muscle dysmorphia: A quest for the hyper muscular body. Motricidade. 2012;8(1):53-66.

5. Carraro A, Nart A, Scarpa S. Effects of a single session of physical exercise on body image. Rev Bras Ciên Esporte. 2010;32(1): 173-184.

6. Gaspar MJM, Amaral TF, Oliveira BMPM, Borges N. Protective effect of physical activity on dissatisfaction with body image in children - A cross-sectional study. Psychol Sport Exercise. 2011;12:563-569.

7. Lepage Ml, Crowther JC. The Effects of exercise on body satisfaction and affect. Body Image. 2010;7(1):124-130.

8. White J, Halliwell E. Examination of a sociocultural model of excessive exercise among male and female adolescents. Body Image. 2010;7(2):227-233.

9. Laus MF, Costa TM, Almeida SS. Body image dissatisfaction and its relationship with physical activity and body mass index in Brazilian adolescents. J Bras Psiquiatr. 2011;60:315-20.

10. Dorgo S, Edupuganti P, Smith DR, Ortiz M. Comparison of lower body specific resistance training on the hamstring to quadriceps strength ratios in men and women. Research Quarterly Exercise Sport. 2012;83:143-151.

11. Gobbo LA, Ritti-Dias RM, Avelar A, Silva AM, Costa-e-Silva MJ, Cyrino E. Changes in skeletal muscle assessed by anthropometric equations after resistance training. Inter J Sports Med. 2013;34(1):28-33. 
12. Moore JB, Mitchell NG, Bibeau WS, Bartholomew JB. Effects of a 12-week resistance exercise program on physical selfperceptions in college students. Research Quarterly Exercise Sport. 2011;82:291-301.

13. Silva-Batista C, Tricoli V, Laurentino GC, Batista MAB, Okuno NM, Ugrinowitsch C. Efeito da familiarização na estabilização dos valores de 1RM para homens e mulheres. Motriz. 2011;17(4):610-617.

14. Polito MD, Cyrino ES, Gerage AM, Nascimento MA, Januário RSB. Efeito de 12 semanas de treinamento com pesos sobre a força muscular, composição corporal e triglicérides em homens sedentários. Rev Bras Med Esporte. 2010;16(1):29-32.

15. Rodgers R, Cabrol H, Paxton SJ. An exploration of the tripartite influence model of body dissatisfaction and disordered eating among Australian and French college women. Body Image. 2011;8(1):208-215.

16. Fortes LS, Ferreira MEC, Vianna JM, Aranda LC, Paes ST, Cyrino ES. Comportamento de checagem corporal e treinamento com pesos: uma investigação com mulheres. Rev Bras Ativ Fis Saude. 2014;19(6):721-731.

17. Chang YK, Etnier JL. Effects of an acute bout of localized resistance exercise on cognitive performance in middle-aged adults: a randomized controlled trial study. Psychol Sport Exercise. 2009;10(1):19-24.

18. Lins-Filho O, Robertson RJ, Farah BQ. Effects of exercise intensity on rating of perceived exertion during a multiple-set resistance exercise session. J Strength Cond Research. 2012;26(2):466-72.

19. Ribeiro AS, Silva DRP, Nascimento MA, Avelar A, Ritti-Dias RM, Cyrino ES. . Effect of the manipulation of exercise order in the tri-set training system. Rev Bras Cineantr Desempenho Hum. 2013;15(5):527-534.

20. Epley B. Poundage chart. Lincoln NE: University of Nebraska; 1995.

21. Adams GM. Exercise physiology laboratory manual. Boston: McGraw-Hill; 1998.

22. Meneses AL, Santana FS, Soares AHG, Souza BCC, Souza DSCA, Santos MAM, Cyrino ES, Ritti-Dias RM. Validade das equações preditivas de uma repetição máxima varia de acordo com o exercício realizado em adultos jovens treinados. Rev Bras Ativ Fís Saúde. 2013;18(1):95-104.

23. Uchida MC, Aoki MS, Navarro F, Tessuti VD, Bacurau RFP. Efeito de diferentes protocolos de treinamento de força sobre parâmetros morfofuncionais, hormonais e imunológicos. Rev Bras Med Esporte. 2006;12(1):21-26.

24. Pinto RS, Félix D, Cadore EL, Cardoso M. Determinaçáo da carga de treino nos exercícios supino e rosca bíceps em mulheres jovens. Motriz. 2012;18(1):22-33.

25. Nascimento MA, Januário RBS, Gerage AM. Familiarization and reliability of one repetition maximum strength testing in older women. J Strength Conditioning Research. 2013;27(6):1636-1642.

26. Lima FV, Chagas MH, Corradi EFF, Silva GF, Souza BB, Moreira Júnior LA. Análise de dois treinamentos com diferentes duraçóes de pausa entre séries baseadas em normativas previstas para a hipertrofia muscular em indivíduos treinados. Rev Bras Med Esporte. 2006;12(4):175-178.

27. Carvalho PHB, Conti MA, Cordás TA, Ferreira MEC. Portuguese (Brazil) translation, semantic equivalence and internal consistency of the Male Body Checking Questionnaire (MBCQ). Rev Psiquiatr Clín. 2012;39(1):74-75.

28. Campana ANNB, Tavares MCGCF, Swami V, Silva D. An Examination of the Psychometric Properties of Brazilian Portuguese Translations of the Drive for Muscularity Scale, the Swansea Muscularity Attitudes Questionnaire, and the Masculine Body Ideal Distress Scale. Psychol Men \& Masculinity. 2012. Advance online publication.

29. Jackson AS, Pollock ML. Generalized equations for predicting body density of men. Br J Nutr. 1978;40:497-504.

30. Internacional Society for Advancement for Kineanthropometry [Internet]. Australia: National Library of Australia [cited 2013 Jul 2013]. Available from: http://www.isakonline.com.

31. Fortes LS, Ferreira MEC, Vianna JM, Aranda LC, Paes ST, Cyrino ES. Comportamento de checagem corporal e treinamento com pesos: uma investigação com mulheres. Rev Bras Ativ Fis Saúde. 2014;19(6):721-731.

\section{Acknowledgments}

To volunteers by collaboration in participation of this study.

ADDRESS
Leonardo de Sousa Fortes
Av. Marechal Hermes da Fonseca, 584, apt 201, Bessa,
$58035-190$ - João Pessoa - PB - BRASIL
e-mail: leodesousafortes@hotmail.com

Submitted: 01/07/2015 1st. Review: 29/09/2015

Accepted: 16/11/2015 